\title{
Kesiapan Lembaga PAUD dalam Pembelajaran Tatap Muka pada New Normal
}

\author{
Muh. Shaleh ${ }^{\circledR}{ }^{凶}$, La Ode Anhusadar ${ }^{2}$ \\ Pendidikan Islam Anak Usia Dini, Institut Agama Islam Negeri Kendari \\ DOI: $10.31004 /$ obsesi.v5i2.1139
}

\begin{abstract}
Abstrak
Penelitian ini dilakukan dengan tujuan untuk mengetahui kesiapan lembaga PAUD dalam menghadapi pembelajaran tatap muka pada masa new normal. Penelitian ini bersifat deskriptif analitik dengan menggunakan data-data kualitatif. Seluruh data dalam penelitian ini diperoleh melalui serangkaian wawancara mendalam kepada sejumlah informan. Informan pada penelitian ini adalah Kepala Sekolah, Guru dan orang tua pada KB Sultan Qaimuddin Kendari dan KB Nurul Maghfirah Kendari. Informan pada penelitian ini ditentukan dengan snowball sampling dan dilakukan mulai bulau November 2020 - Januari tahun 2021. Peneliti menggunakan teknik pengumpulan data berupa observasi, dokumentasi, dan wawancara. Temuan dalam penelitian ini adalah persiapan lembaga PAUD dalam pembelajaran tatap muka pasca covid-19 dengan penerapan protokol kesehatan yang telah di tetapkan oleh pemerintah, baik pemerintah pusat maupun pemerintah daerah.
\end{abstract}

Kata kunci: new normal; pembelajaran tatap muka; pendidikan anak usia dini

\begin{abstract}
The Purpose of this research is of seeing the readiness of PAUD institutions in facing face-toface learning in the new normal period. This research is descriptive analytic using qualitative data. All data in this study were obtained through in-depth interviews with a number of information.. The informants in this study were parents who had children who were pursuing Early Childhood Education in Kendari, namely Sultan Qaimuddin Kendari KB and KB Nurul Maghfirah Kendari. Information in this study was determined by snowball sampling and carried out from November 2020 - January 2021. Researchers used data techniques in the form of observation, documentation, and interviews. The findings in this study are PAUD preparation institutions in face-to-face learning after Covid-19 by implementing health protocols that have been established by the government, both central and local governments.
\end{abstract}

Keywords: new normal , face to face learning, early childhood education programs

Copyright (c) 2021 Muh. Shaleh, La Ode Anhusadar

$\triangle$ Corresponding author:

Email Address : muhshaleh@iainkendari.ac.id (Kendari, Sulawesi Tenggara, Indonesia)

Received 10 February 2021, Accepted 22 February 2021, Published 3 March 2021

\section{PENDAHULUAN}

Covid-19 telah membawa dampak pada seluruh sektor kehidupan manusia, tak terkecuali pada sektor pendidikan. Sudah beberapa bulan lembaga-lembaga pendidikan harus melakukan pembelajaran jarak jauh (PJJ) secara daring tak terkecuali dengan lembaga PAUD juga harus melakukan pembelajaran daring. Pendidikan pada lembaga PAUD memang 
berbeda dengan pendidikan di tingkat yang lebih tinggi. Karakter anak-anak yang khas sangat membutuhkan pendampingan dan bimbingan orang dewasa di sekitarnya. Perlu kerja keras untuk bisa menerapkan new normal pada pendidikan anak. Protokol kesehatan di sekolah merupakan aturan untuk mencegah meluasnya penyebaran penyakit Covid-19 yang diakibatkan virus Corona di institusi pendidikan. Dalam buku saku Panduan Penyelenggaraan Pembelajaran di Masa Pandemi Covid-19 yang disusun Kemendikbud, Kemenkes, Kementerian Agama, dan Kementerian Dalam Negeri pembelajaran tatap muka dilaksanakan melalui dua fase yakni masa transisi dan masa kebiasaan baru atau new normal. Pembelajaran tatap muka di satuan pendidikan pada zona hijau dilakukan dengan penentuan prioritas berdasarkan jenjang pendidikan yang lebih tinggi terlebih dahulu dan mempertimbangkan kemampuan peserta didik untuk menerapkan protokol kesehatan dan menjaga jarak (physical distancing) dengan ketentuan PAUD formal (Taman Kanak-kanak (TK), Raudatul Athfal (RA), dan TK Luar Biasa) dan nonformal paling cepat 2 (dua) bulan setelah SD, MI, Paket A dan SLB melaksanakan pembelajaran tatap muka di satuan pendidikan(Kemdikbud, 2020).

Proses pembelajaran dari rumah melalui pembelajaran online idealnya tetap dapat mengakomodasi kebutuhan belajar siswa untuk mengembangkan bakat dan minat sesuai dengan jenjang pendidikannya. Untuk mewujudkan hal tersebut diperlukan kesiapan pendidik, kurikulum yang sesuai, ketersediaan sumber belajar, serta dukungan peranti dan jaringan yang stabil sehingga komunikasi antar peserta didik dan pendidik dapat efektif. Kondisi pembelajaran online saat ini belum dapat disebut ideal sebab masih terdapat berbagai hambatan yang dihadapi. Hambatan tersebut sekaligus menjadi tantangan dalam pelaksanaan pembelajaran online mengingat pelaksanaan pembelajaran online merupakan keharusan agar kegiatan pendidikan tetap dapat terselenggara di tengah darurat pandemi Covid-19 yang terjadi saat ini. Hasil penelitian Kim menyimpulkan bahwa It is necessary to provide student teachers with opportunities and skills for such online teaching, including interacting with children through this medium, and also have students reflect about how best to promote development and learning using online communication tools(Kim, 2020). Hambatan yang dihadapi dalam pelaksanaan pembelajaran online antara lain berkaitan dengan kesiapan sumber daya manusia, kurang jelasnya arahan pemerintah daerah, belum adanya kurikulum yang tepat, dan keterbatasan sarana dan prasarana, khususnya dukungan teknologi dan jaringan internet. Metode pembelajaran yang digunakan masih dominan pemberian tugas kepada peserta didik. Banyak pendidik PAUD yang tidak setuju dengan pembelajaran online karena tidak efektif dan tidak semua orang tua yang memiliki Laptop atau HP untuk pembelajaran online(Nurdin \& Anhusadar, 2020). Kesiapan sumber daya manusia meliputi pendidik (guru dan dosen), peserta didik, dan dukungan orang tua merupakan bagian terpenting dalam pelaksanaan pembelajaran online (Arifa, 2020).

Proses pembelajaran online diharapkan tetap menjadi solusi dalam masa pandemi ini. Dengan banyaknya hambatan yang dihadapi dalam proses pembelajaran online pendidik harus tetap melakukan tugasnya untuk mendidik. Metode pembelajaran yang digunakan juga harus sesuai dengan kondisi lingkungan yang ada . Pada saat ini di Indonesia sedang mengalami situasi yang tidak diinginkan. Adanya kasus wabah COVID-19 tidak menjadikan pembelajaran berhenti, tetapi pembelajaran juga harus tetap berjalan. Kebijakan yang telah tercantum menyatakan bahwa pembelajaran tetap berjalan dirumah dengan pembelajaran daring(Hutami \& Nugraheni, 2020). Hambatan dalam pembelajaran online ini diungkapkan oleh penelitian Wulandari misalnya mengungkapkan bahwa sistem pembelajaran online atau daring pada masa pandemi covid 19 ini memberikan pengaruh negatif terhadap pencapaian perkembangan anak usia dini di TK (Wulandari et al., 2021). Kegiatan transformasi nilai pendidikan Islam anak masih dilakukan dimasa pandemi covid 19, walaupun tidak semua nilai agama ditanamkan pada anak. Proses transformasi nilai pendidikan Islam anak dilakukan oleh guru bersama orang tua melalui komunikasi online (whatsapp) mengalami hambatan, tidak seperti aktifitas tatap muka (Aris Try Andreas Putra, Sufiani, 2020). 
Pendidikan Anak Usia Dini merupakan pendidikan yang diselenggarakan untuk mengembangkan keterampilan yang merupakan pendidikan dasar serta mengembangkan diri secara utuh sesuai dengan asas pendidikan sedini mungkin dan sepanjang hayat. Aspek yang dikembangkan dalam pendidikan anak usia dini adalah aspek pengembangan pembiasaan meliputi sosial, emosi, kemandirian, moral, dan nilai-nilai agama, serta pengembangan kemampuan dasar yang meliputi pengembangan bahasa, kognitif, dan fisik motorik(Suriati et al., 2019). Kesiapan lembaga PAUD dalam menyiapkan pembelajaran tatap muka memang sangat diperlukan untuk memberikan kenyamanan kepada peserta didik untuk dapat terhindar dari tertular dari virus covid-19. Mengukur kesiapan lembaga PAUD dalam menyiapkan proses pembelajaran tatap muka sangat perlu dilakukan sehingga bisa mengukur kesiapan yang dilakukan oleh lembaga PAUD dalam menyiapkan fasilitas yang sesuai dengan petunjuk dari pemerintah. Hasil penelitian yang dilakukan oleh Dinda menyimpulkan bahwa kesiapan guru dalam pembelajaran akan menentukan kesiapan lembaga untuk melakukan pembelajaran daring pula. Kesiapan guru dalam pembelajaran daring di lembaga pendidikan anak usia ini dapat diukur melalui indikator-indikator yang meliputi ranah sosial emosional, kognitif, pedagogi, kemampuan penggunaan teknologi serta kemampuan berkomunikasi yang disesuaikan dengan kebutuhan dan karakteristik subjek yang lingkungan subjek. Sehingga alat ukur yang digunakan mampu memberikan data yang tepat agar dapat melakukan pembelajaran daring dengan baik dan mampu mengembangkan kemampuan anak (Rizki Tiara \& Pratiwi, 2020).

\section{METODOLOGI}

Penelitian ini bersifat deskriptif analitik dengan menggunakan data-data kualitatif. Seluruh data dalam penelitian ini diperoleh melalui serangkaian wawancara mendalam kepada sejumlah informan. Untuk memperkuat dan memperkaya data yang diperoleh melalui wawancara, penulis juga melakukan pengamatan langsung serta mengkaji sejumlah dokumen yang berhubungan dengan subastansi masalah. Informan pada penelitian ini adalah Kepala Sekolah, Guru dan orang tua pada KB Sultan Qaimuddin Kendari dan KB Nurul Maghfirah Kendari. Informan pada penelitian ini ditentukan dengan snowball sampling dan dilakukan mulai bulan November 2020-Januari tahun 2021. Teknik pengumpulan data menggunakan observasi, wawancara dan dokumentasi. Analisis data dalam penelitian ini ialah Koleksi data, reduksi data, penyajian data dan kesimpulan(Sugiyono, 2007).

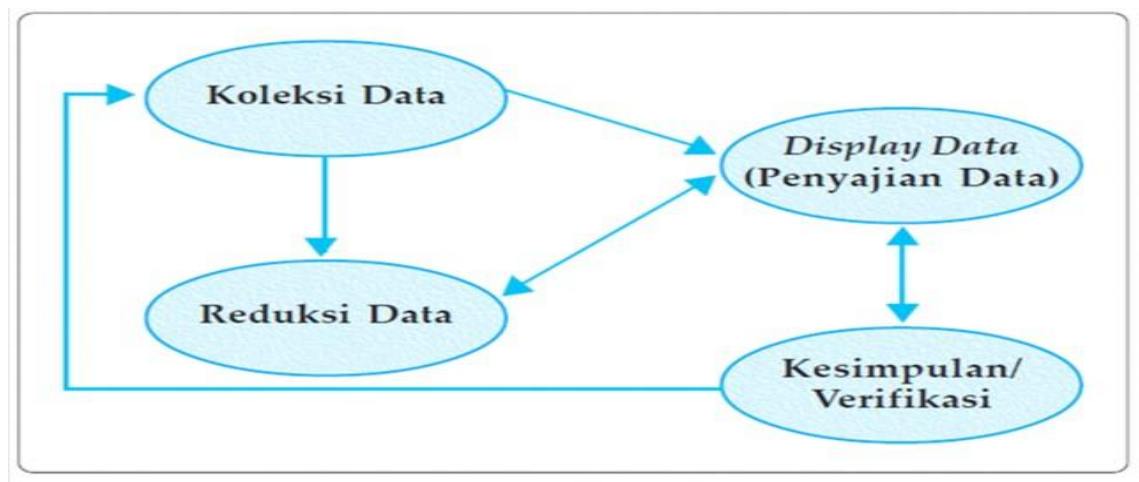

Gambar 1. Analisis data kualitatif menurut Miles dan Huberman ((Sugiyono, 2008)

\section{HASIL DAN PEMBAHASAN}

Pembelajaran di rumah selama pandemic covid-19 tidaklah semudah yang dibayangkan. Faktor kurangnya semangat anak dan kurangnya kemampuan orang tua dalam mendampingi anak menjadi tantangan dalam penerapan pembelajaran. Salah seorang orangtua peserta didik mengatakan ternyata tidak semua orangtua bisa seperti guru di sekolah. Banyak orang tua tidak sabar, anak biasanya malah dibentak-bentak yang juga 
efeknya kurang bagus. Mungkin karena keadaan situasi dan kondisi, anak jadi kurang semangat di rumah sehingga jenuh, tidak ada teman-teman, dan tidak ada yang memotivasi (Wawancara, AS tanggal 9 Desember 2020). Pendapat lain dikemukakan oleh orangtua peserta didik mengatakan bahwa selama masa pandemic covid-19 ini proses pembelajaran anak-anak kami tidak efektif karena kebanyakan pembelajarannya guru memberikan tugas untuk dikerjakan di rumah, dan pada saat belajar di rumah, kami sebagai orang tua harus turut membantu mengerjakan tugasnya. Orangtua mendapatkan tugas tambahan lagi selain tugas dari kantor (wawancara, M tanggal 9 Desember 2020). Metode pemberian tugas banyak digunakan oleh pendidik PAUD dalam pembelajaran pada masa pandemic covid-19 ini. Sebagai mana hasil penelitian Nurdin yang menyimpulkan bahwa metode pembelajaran yang digunakan masih dominan pemberian tugas kepada peserta didik (Nurdin \& Anhusadar, 2020). Menurut Ayuni terdapat beberapa faktor yang membuat guru belum siap menghadapi pembelajaran daring, yaitu fasilitas yang kurang memadai baik dari pihak guru maupun dari pihak orang tua, dan masih terdapat orang tua yang menganggap bahwa pembelajaran daring ini sulit dilakukan(Ayuni et al., 2020). Penelitian Aruming juga menyimpulkan bahwa pelaksanaan pembelajaran E-Learning yang di lakukan oleh guru PAUD selama pandemic Covid-19 tidak efektif karena banyaknya guru mengalami kendala dalam segi pelaksanaan dan segi prasarana (Pudyastuti \& Budiningsih, 2021). Perlunya kerjasama dengan pihak orang tua dengan melakukan komunikasi efektif berkaitan dengan kegiatan pembelajaran yang dilakukan selama pembelajaran dari rumah karena pelaksana kegiatan adalah orang tua(Maryani, 2020). Orangtua mengkondisikan lingkungan keluarga dengan menjadikan rumah sebagai tempat yang nyaman untuk menunjang pendidikan anak (Tanjung, 2020)

Kondisi Pandemi Covid-19 pada akhirnya membuat lembaga pendidikan khususnya pada lembaga PAUD harus siap dengan pola pendidikan yang ditetapkan oleh pemerintah dengan penerapan new normal pada lembaga PAUD. Rencana pemerintah dalam membuka kembali pembelajaran tatap muka di sekolah menjadi angin segar untuk pendidikan karena proses pembelajaran akan dilakukan seperti biasa di sekolah. Namun untuk membuka kembali pembelajaran tatap muka di sekolah pemerintah memberikan syarat kepada masingmasing lembaga pendidikan untuk memenuhi protokol kesehatan. Sebagai mana persayaratan yang dikemukakan oleh Kemendikbud juga mengatur jumlah maksimal siswa di dalam suatu kelas. Untuk tingkat sekolah menengah dan sekolah dasar dibatasi hanya maksimal 18 peserta didik per kelas, sedangkan untuk SLB dan PAUD maksimal 5 orang per kelas. Jarak antar-siswa di tingkat SD-SMP-SMA diatur minimal 1,5 meter. Sementara untuk tingkat PAUD, para siswa harus berjarak minimal 3 meter saat berada di dalam kelas(Redaktur, 2020).

Dengan rencana dibukanya kembali pembelajaran tatap muka di sekolah, tentu lembaga pendidikan khususnya lembaga PAUD harus menyiapkan kebutuhan yang sesuai dengan protokol kesehatan. Sehingga persyaratan untuk membuka kembali lembaga PAUD bisa dipenuhi. Salah seorang pendidik PAUD mengatakan bahwa terkait dengan persyaratan yang dibutuhkan untuk pembukaan pembelajaran yang dari dinas pendidikan tentu PAUD kami akan penuhi, seperti peserta didik dan guru wajib menggunakan masker, mengecek suhu tubuh, waktu kegiatan belajar mengajar, jarak antar peserta didik di dalam kelas, dan kegiatan di luar kegiatan belajar mengajar dengan tetap menjaga protokol kesehatan (Wawancara bu Guru M, 10 Desember 2020). Hal senada juga di sampaikan oleh pendidik PAUD bahwa ketentuan yang telah di tetapkan oleh dinas pendidikan kami akan penuhi persyaratannya dengan tetap menjaga protokol kesehatan baik dengan sehingga pendidik dan peserta didik merasa nyaman dan aman dalam menjalankan pembejaran tatap muka di sekolah (Wawancara bu guru LA, 10 Desember 2020). Persyaratan untuk membuka pembelajaran tatap muka telah disampaikan oleh dinas pendidikan kota kendari yang disebarkan keseluruh lembaga PAUD yang ada di kota Kendari sebagai berikut : menyediakan sarana cuci tangan, menyediakan sarana desinfektan, menyediakan thermogun, 
menyediakan masker, menyediakan media penyuluhan dan menyediakan penanda pembatasan jarak antar siswa di setiap kelas.

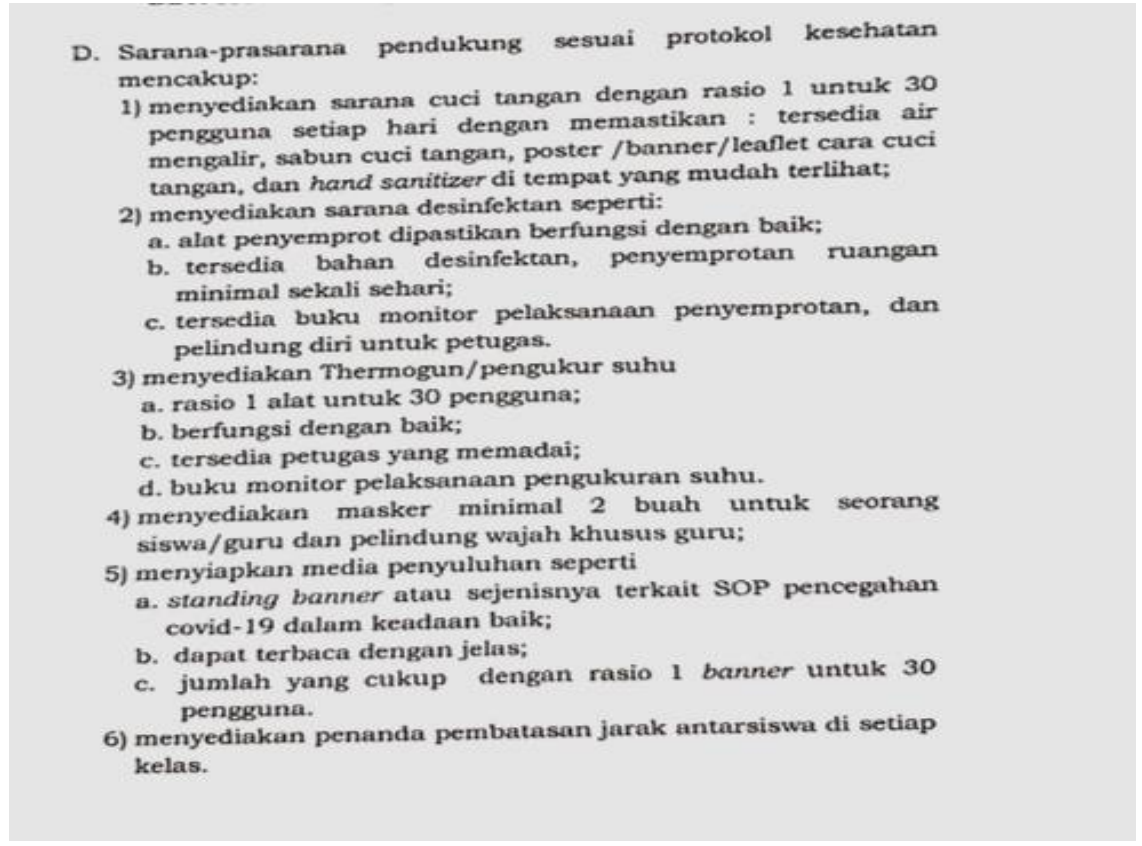

\section{Gambar 1. Panduan Pembelajaran Tatap Muka di Kota Kendari}

Gambar satu di atas merupakan panduan persiapan pembelajaran tatap muka masa darurat covid-19 tahun 2020/2021 yang diterbitkan oleh pemerintah Kota Kendari melalui Dinas Pendidikan Kepemudaan dan Olahraga Kota Kendari yang menjadi acauan untuk lembaga pendidikan untuk membuka pembelajaran tatap muka. Salah satu point persyaratan untuk membuka pembelajaran tatap muka adalah lembaga pendidikan menyediakan masker minimal 2 buah untuk seorang siswa/guru dan pelindung wajah khusus untuk guru. Penggunaan masker pada masa pandemic covid-19 ini sangat dianjurkan terlebih untuk anakanak yang masuk dalam kategori yang rentang dengan penularan covid-19. Dengan menggunakan masker bisa mencegah dari penularan dan mencegah menulari orang lain dari virus covid-19. Protokol kesehatan yang dijalankan secara konsisten dan tepat, disertai dengan strategi pencegahan yang tepat, dapat berpotensi memperlambat penyebaran Covid-19. Salah satu protokol kesehatan di era new normal yang harus diterapkan adalah menggunakan masker, baik masker kain maupun masker medis. Untuk peserta didik kami wajibkan penggunaan masker selama berada di sekolah, baik yang menggunakan masker kain maupun masker medis, untuk anak-anak yang lupa menggunakan masker kami meminta orangtua untuk mengambil kembali di rumah sehingga anak-anak terbiasa menggunakan masker dalam kehidupannya sehari-hari (wawancara bu guru LA, 10 Desember 2020). Sementara itu orangtua peserta didik sangat mendukung peraturan yang mewajibkan peserta didik dalam penggunaan masker, sebagai mana yang di ungkapkan oleh NI bahwa saya setuju jika anakanak wajib menggunakan masker dalam pembelajaran tatap muka di sekolah, dengan masker ini anak-anak bisa terhindar dari penyebaran virus covid-19 (wawancara NI. 10 Desember 2020). Menurut Organisasi Kesehatan Dunia (WHO) dan The United Nations Children's Fund (Unicef) pada laman WHO kebijakan nasional yang dianjurkan untuk penggunaan masker pada anak-anak berdasarkan usia, yaitu: anak-anak yang masih berusia di bawah 5 tahun dianjurkan untuk tidak mengenakan masker. Saran ini berdasar pada pertimbangan dengan pendekatan "tidak menyakiti": Usia di bawah 5 tahun merupakan awal dari momen perkembangan anak-anak, Anak masih dalam tahap penyesuaian pada sebuah peraturan dan perlu otonomi untuk dapat memakai masker dengan benar(Ega Krisnawati, 2020). Hasil penelitian untari menyimpulkan bahwa dikabupaten Grobogan sebagian besar dari 
masyarakatnya telah menggunakan masker saat keluar dari rumah, meskipun masih ada sebagian kecil masyarakat yang belum menggunakan masker. Dibutuhkan kesadaran yang tinggi untuk sama-sama saling membantu memutus mata ramtai penularan Covid-19. Penggunaan masker dimasa pandemi ini sangat penting untuk melindungi diri dan orang lain (Pratiwi, 2020). Penggunaan masker kepada peserta didik sudah dibiasakan oleh guru dan orangtua ketika peserta didik mengumpulkan tugas di sekolah yang diberikan oleh guru sebagaimana terlihat pada gambar 2 peserta didik menggunakan masker dalam pembelajaran tatap muka.
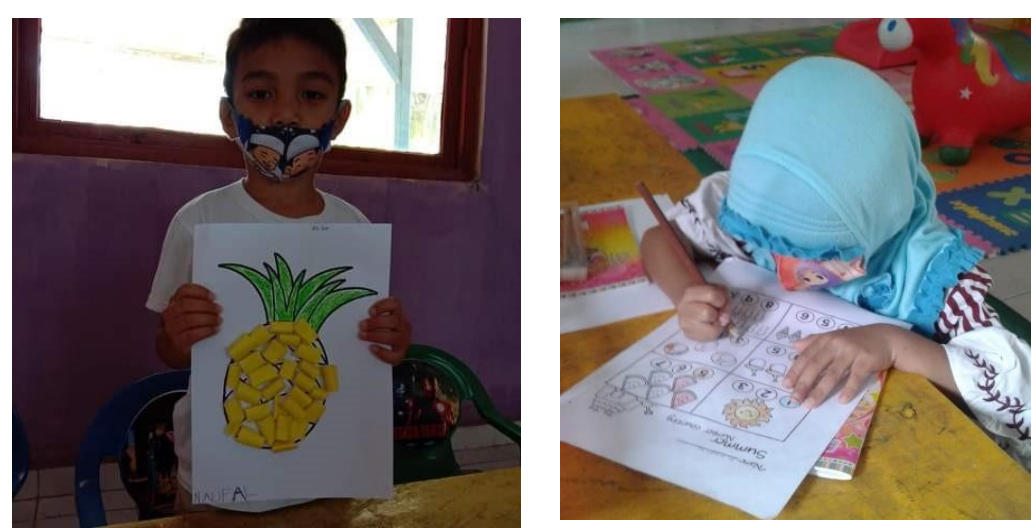

Gambar 2. Peserta didik menggunakan masker dalam pembelajaran tatap muka.

Pelaksanan pembelajaran tatap muka yang telah dirancang oleh lembaga PAUD harus mendapatkan izin dari orangtua peserta didik. Sebagaimana yang dikemukakan salah seorang guru bahwa orangtua peserta didik harus setuju dengan pelaksanaan pembelajaran tatap muka dan menandatangani surat pernyataan (Wawancara, Ibu guru M, 10 Desember 2020). Respon orangtua peserta didik terkait dengan pelaksanaan pembelajaran tatap muka ini sangat setuju, sesuai hasil wawancara dengan salah seorang orangtua bahwa kami sangat setuju dengan pelaksanaan pembelajaran tatap muka di sekolah dengan penerapan protokol kesehatan (Wawancara ST, 10 Desember 2020). Hal lain diungkapkan oleh orangtua peserta didik bahwa kami senang jika pembelajaran tatap muka lagi, anak-anak kami sudah lama belajar di rumah, kami takut anak kami jenuh dalam belajar karena anak-anak belajar sendiri di rumah. Olehnya itu kami menandatangi surat pernyataan kesediaan untuk anak-anak belajar tatap muka lagi di sekolah (Wawancara H, 10 Desember 2020). Surat pernyataan kesedian orangtua disiapkan oleh lembaga PAUD beserta materai untuk ditanda tangani oleh orangtua sebagaimana terlihat pada gambar 3, surat peryataan kesediaan orangtua yang ditanda tangani di atas materai sebagai salah satu syarat untuk pembelajaran tatap muka.

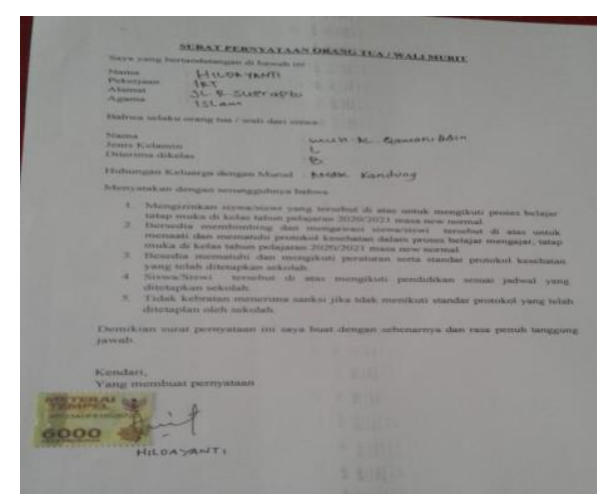

Gambar 3. Orangtua menandatangi surat pernyataan

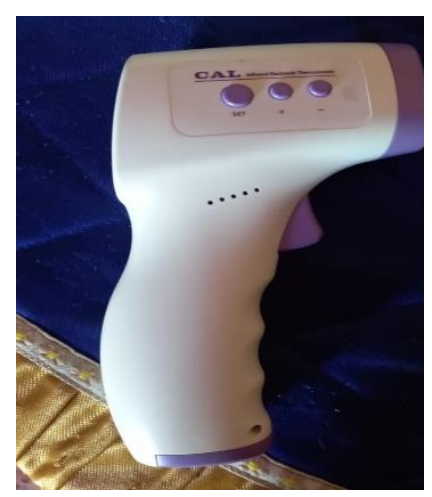

Gambar 4. Alat

Pengukur Suhu

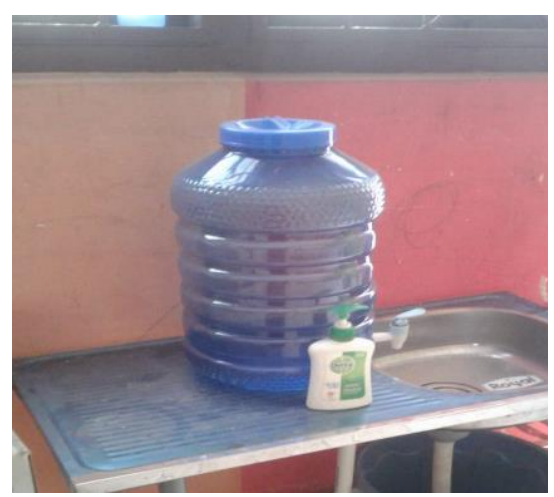

Gambar 5. Sabun dan tempat Cuci tangan 
Pada gambar 4 di atas terlihat alat pengukur suhu atau thermogun yang disiapkan oleh lembaga PAUD untuk mengukur suhu tubuh peserta didik di sekolah. Melakukan skrining kesehatan dan menjaga kebersihan dalam proses pembelajaran tatap muka harus dilakukan secara kontinyu. Skrining dilakukan kepada semua orang yang terlibat dalam pendidikan terutama guru, anak didik, dan orang tua anak. Skrining bisa dimulai sebelum meninggalkan rumah, apakah ada gejala-gejala yang dicurigai terinfeksi Covid-19. Jika terdapat gejala, disarankan untuk tetap berada di rumah. Selain itu, pengukuran suhu badan saat memasuki lingkungan sekolah juga harus dilakukan. Sebaiknya orangtua terlibat dalam skrinning anak dari rumah sehingga jika ada gejala, pihak lembaga bisa cepat mengantisipasi dan tidak menularkan kepeserta didik yang lain, untuk di sekolah kami telah menyiapkan alat pengukur suhu tubuh untuk menskrining suhu tubuh peserta didik (Wawancara Ibu guru NM, 10 Desember 2020). Senada dengan SJ orangtua peserta didik yang mengemukakan bahwa orangtua juga harus ikut serta menjaga kesehatan anak-anak sebelum kesekolah dan setelah pulang sekolah, jangan menyerahkan semua tanggung jawab ke pihak lembaga PAUD, lembaga PAUD sudah menyiapkan alat mengukur suhu anak di sekolah, maka kita juga harus menyiapkan di rumah (Wawancara SJ, 10 Desember 2020).

Fasilitas yang memadai dan mudah dijangkau untuk mencuci tangan harus disiapkan oleh lembaga PAUD sebagaimana terlihat pada gambar 5 di atas yang dibuat dengan menyesuaikan tinggi dari peserta didik. Ajari anak cara cuci tangan yang benar sesuai yang dianjurkan oleh WHO. Kebersihan lingkungan sekolah, ruang kelas dan peralatan yang digunakan juga harus rutin dilakukan. Penyemprotan disinfektan pada permukaan yang sering dipegang, seperti gagang pintu, gagang keran, mainan dan sebagainya. Untuk kebiasaan mencuci tangan peserta didik sudah baik, karena sebelum pandemic covid-19 kami sudah biasakan peserta didik untuk mencuci tangan sebelum dan setelah makan, setelah bermain, dan setelah dari toilet. Sehingga pada masa pandemic ini peserta didik sudah terbiasa mencuci tangan dan kami menyiapkan sabun dan tempat mencuci tangan dengan air yang mengalir (Wawancara Ibu guru LA, 10 Desember 2020). Kebiasaan dalam cuci tangan menggunakan air saja tidak dapat melindungi setiap individu dari bakteri dan virus yang terdapat di tangan. Terlebih jika mencuci tangan tidak di bawah air mengalir. Apalagi kebiasaan menggunakan dan berbagi wadah cuci tangan hal itu sama saja saling berbagi kuman dan tetap membiarkan kuman menempel pada tangan. Kebiasaan itu harus ditinggalkan dan dirubah menjadi yang lebih baik dengan standar prosedur melakukan cuci tangan menggunakan sabun (Kemenkes RI, 2014). Cara cuci tangan pakai sabun yang benar adalah menggosok telapak tangan secara bersamaan, menggosok punggung kedua tangan, jalinkan kedua telapak tangan lalu digosok-gosokkan, tautkan jari-jari antara kedua telapak tangan secara berlawanan, gosok ibu jari secara memutar dilanjutkan dengan daerah antara jari telunjuk dan ibu jari secara bergantian, gosok kedua pergelangan tangan dengan arah memutar, bilas dengan air dan keringkan. Hal terpenting dalam CTPS bukan berapa lama waktu mencuci tangan, tetapi cara mencuci tangannya (Kemenkes RI, 2014). Menggunakan sabun saat mencuci tangan diketahui sebagai salah satu upaya pencegahan penyakit dan penularan penyakit. Hal ini dilakukan karena tangan merupakan agen yang membawa kuman dan menyebabkan patogen berpindah dari satu orang ke orang lain, baik dengan kontak tidak langsung maupun kontak langsung (menggunakan permukaan lain seperti handuk dan gelas) (Kemenkes RI, 2014). Membentuk pola hidup sehat lebih mudah daripada mengubah perilaku hidup sehat. Sekali lagi tugas membentuk perilaku sehat pada anak usia dini bukan menjadi tugas orang tua semata, melainkan juga pihak sekolah. Antara sekolah dan orang tua harus bekerja sama supaya anak usia dini memperoleh pendidikan tentang pola hidup sehat, sehingga dapat menjadi jaminan untuk hari depan tubuh yang sehat. Tentu saja, dibandingkan dengan sekolah, maka orang tua mempunyai peran yang lebih besar dalam membentuk perilaku sehat ini. Karena orang tua adalah pendidik yang pertama dan utama (Syahreni, 2011). 
Perilaku hidup bersih dan sehat (PHBS) adalah hal wajib yang harus dilakukan di lingkungan sekolah untuk mencegah penularan virus. Perilaku hidup bersih dan sehat menjadi rutinitas bahkan keharusan. Bagaimana tidak, ancaman penyebaran Covid-19 yang sangat mudah meluas. Virus ini mampu bertahan hidup di berbagai jenis benda dalam beberapa jam, bahkan ada yang sampai beberapa hari. Menurut hasil penelitian Anhusadar menyimpulkan bahwa Perilaku hidup bersih dan sehat anak usia dini di lingkungan keluarga sudah berjalan sangat baik di tengah pademi covid 19 (Anhusadar \& Islamiyah, 2020). Hasil penelitian Safitri menyimpulkan bahwa membiasakan pola hidup sehat pada anak pada masa pandemi covid-19 dapat dilakukan dengan cara mengingatkan anak untuk memakanmakanan yang bergizi seperti sayur dan buah, berolahraga teratur dan istirahat yang cukup serta berjemur setiap pagi sekitar 10-15 menit (Safitri \& Harun, 2020). Menurut Notoatmojo beberapa hal yang perlu diajarkan pada anak untuk mengembangkan perilaku sehat, yaitu menjaga kebersihan diri maupun kebersihan lingkungan dan menjauhkan hal-hal yang berbahaya untuk kesehatan. Kebersihan lingkungan adalah kebersihan tempat tinggal, tempat kerja atau bermain, dan sarana umum(Notoadmodjo S, 2010).

Pendidik dalam menerapkan pembelajaran tatap muka harus memperhatikan jarak antar peserta didik. Selain itu, fasilitas harus mengikuti pedoman standar untuk mencegah penyebaran virus, seperti pengaturan tempat duduk dengan jarak yang dianjurkan, fasilitas cuci tangan dan menjaga kebersihan semua peralatan yang digunakan anak. Melakukan social/physical distancing di taman kanak-kanak. Hal yang dapat dilakukan yakni membatasi jumlah anak maksimal 10 anak per rombel dalam satu kelas. Mengatur ruang kelas, mengatur jarak minimal enam kaki di setiap pusat kegiatan anak, meja, dan kursi anak. Kembangkan kegiatan dengan model dan menerapkan praktik kebersihan dan social/physical distancing yang baik. Gunakan bahan-bahan ruang kelas untuk membantu anak-anak memvisualisasikan jarak enam kaki antara orang yang diperlukan. Ingatkan anak-anak untuk tidak berbagi makanan, minuman, peralatan main kepada temannya. Pengaturan social distancing orang tua anak saat jam antar dan jemput sekolah. Kegiatan bermain merupakan metode yang tepat digunakan dalam lembaga PAUD untuk menstimulasi perkembangan anak dengan melakukan kegiatan yang serius namun tetap menyenangkan dan menghibur bagi anak (Widiastita \& Anhusadar, 2020). Memang sepertinya sulit memberlakukan social distancing di taman kanak-kanak, mengingat kegiatan di TK yang biasa dilakukan secara berkelompok. Namun, selama masa pandemi semua kegiatan harus menekankan pada aktivitas secara individual

\section{SIMPULAN}

Persiapan lembaga PAUD dalam pembelajaran tatap muka pasca covid-19 dengan penerapan protokol kesehatan yang telah di tetapkan oleh pemerintah, baik pemerintah pusat maupun pemerintah daerah. Persiapan lembaga PAUD diantaranya adalah peserta didik dan guru wajib menggunakan masker, mengecek suhu tubuh, waktu kegiatan belajar mengajar, jarak antar peserta didik di dalam kelas, dan kegiatan di luar kegiatan belajar mengajar dengan tetap menjaga protokol kesehatan. Pengunaan masker baik masker kain maupun masker bedah, penerapan perilaku hidup bersih dan sehat serta pelibatan orangtua dalam menskrining peserta didik sangat diharapkan sehingga dapat mencegah peserta didik dari penularan virus covid-19 di lingkungan sekolah.

\section{UCAPAN TERIMA KASIH}

Terima kasih penulis ucapkan kepada kepala sekolah dan guru KB Sultan Qaimuddin Kendari dan KB Nurul Maghfirah Kendari dan Orang tua dan semua pihak yang telah membantu pelaksanaan penelitian dan penulisan artikel ini. Tidak lupa ucapan terima kasih kepada editor dan reviewer Journal Obsesi yang sudah memberikan kesempatan sehingga jurnal bisa untuk diterbitkan. 


\section{DAFTAR PUSTAKA}

Anhusadar, L., \& Islamiyah, I. (2020). Penerapan Perilaku Hidup Bersih dan Sehat Anak Usia Dini di Tengah Pandemi Covid 19. Jurnal Obsesi : Jurnal Pendidikan Anak Usia Dini, 5(1), 463. https://doi.org/10.31004/obsesi.v5i1.555

Arifa, F. N. (2020). Tantangan Pelaksanaan Kebijakan Belajar Dari Rumah Dalam Masa Darurat Covid-19. Info Singkat;Kajian Singkat Terhadap Isu Aktual Dan Strategis, XII(7/I), 6. http:// berkas.dpr.go.id/puslit/files/info_singkat/Info Singkat-XII-7-I-P3DI-April2020-1953.pdf

Aris Try Andreas Putra, Sufiani, J. (2020). Transformasi Nilai Pendidikan Islam Anak di PAUD Sultan Qaimuddin Kendari Pada Masa Pandemi Covid 19. Murhum : Jurnal Pendidikan Anak Usia Dini, 1(1). https:/ / doi.org/10.37985/murhum.v1i1.8

Ayuni, D., Marini, T., Fauziddin, M., \& Pahrul, Y. (2020). Kesiapan Guru TK Menghadapi Pembelajaran Daring Masa Pandemi Covid-19. Jurnal Obsesi : Jurnal Pendidikan Anak Usia Dini, 5(1), 414. https:/ / doi.org/10.31004/obsesi.v5i1.579

Ega Krisnawati. (2020). Cara Memakai Masker pada Anak Menurut WHO untuk Cegah COVID-19. Tirto.Id.

Hutami, M. S., \& Nugraheni, A. S. (2020). Metode Pembelajaran Melalui Whatsapp Group Sebagai Antisipasi Penyebaran Covid-19 pada AUD di TK ABA Kleco Kotagede. Paudia: Jurnal Penelitian Dalam Bidang Pendidikan Anak Usia Dini, 9(1), 126-130. https:/ / doi.org/https:/ / doi.org/10.26877/paudia.v9i1.6107

Kemdikbud. (2020). Panduan Penyelenggaraan Pembelajaran di Masa Pandemi COVID-19. Kemendikbud, 2019, 1-58. https://www.kemdikbud.go.id/main/blog/2020/06/bukusaku-panduan-pembelajaran-di-masa-pandemi-covid19

Kemenkes RI. (2014). Profil Kesehatan Indonesia. Kementrian Kesehatan Indonesia. In Pusdatin.Kemenkes.Go.Id. Kemenkes.

Kim, J. (2020). Learning and teaching online during Covid-19: experiences of student teachers in an early childhood education practicum. International Journal of Early Childhood, 52(2), 145-158. https:/ / doi.org/10.1007/s13158-020-00272-6

Maryani, K. (2020). Penilaian dan Pelaporan Perkembangan Anak Saat Pembelajaran di Rumah di Masa Pendemi Covid-19. Murhum, 1(2), 41-52. https:// doi.org/10.37985/murhum.v1i1.4

Notoadmodjo S. (2010). Promosi kesehatan teori dan aplikasi. Rineka Cipta.

Nurdin, N., \& Anhusadar, L. (2020). Efektivitas Pembelajaran Online Pendidik PAUD di Tengah Pandemi Covid 19. Jurnal Obsesi : Jurnal Pendidikan Anak Usia Dini, 5(1), 686. https:// doi.org/10.31004/obsesi.v5i1.699

Pratiwi, A. D. (2020). Gambaran Penggunaan Masker di Masa Pandemi Covid-19 Pada Masyarakat di Kabupaten Muna. Literacy Institute, 5(2), 52-57. https:// www.mendeley.com/catalogue/ ee828287-9e25-37b2-aeb8-

a92b94ed347c/?utm_source=desktop\&utm_medium=1.19.4\&utm_campaign=open_c atalog\&userDocumentId=\%7Bb93b070a-115c-4260-854c-e57f42c47e86\%7D

Pudyastuti, A. T., \& Budiningsih, C. A. (2021). Efektivitas Pembelajaran E-Learning pada Guru PAUD Selama Pandemic Covid-19. Jurnal Obsesi: Jurnal Pendidikan Anak Usia Dini, 5(2), 1667-1675. https:// doi.org/10.31004/obsesi.v5i2.873

Redaktur. (2020). Persiapan Pembelajaran Era New Normal. KumparanNews. https:// kumparan.com/kumparannews/ persiapan-pembelajaran-era-new-normal1tcVKcbeIB8/full

Rizki Tiara, D., \& Pratiwi, E. (2020). Mengukur Kesiapan Guru Sebagai Dasar Pembelajaran Daring Di Lembaga PAUD. Jurnal Golden Age, 4(02), 362-368. https:// doi.org/10.29408/jga.v4i02.2624

Safitri, H. I., \& Harun, H. (2020). Membiasakan Pola Hidup Sehat dan Bersih pada Anak Usia Dini Selama Pandemi Covid-19. Jurnal Obsesi : Jurnal Pendidikan Anak Usia Dini, 5(1), 385. https://doi.org/10.31004/obsesi.v5i1.542 
DOI: 10.31004/obsesi.v5i2.1139

Sugiyono. (2007). Metode Penelitian Kuantitatif, Kualitatif dan RED. Alfabeta.

Sugiyono. (2008). Metode Peneltian Kuantitatif Kualitatif dan R \& D. Alfabeta Bandung.

Suriati, S., Kuraedah, S., Erdiyanti, E., \& Anhusadar, L. O. (2019). Meningkatkan Keterampilan Motorik Halus Anak melalui Mencetak dengan Pelepah Pisang. Jurnal Obsesi : Jurnal Pendidikan Anak Usia Dini, 4(1), 211. https:/ / doi.org/10.31004/obsesi.v4i1.299

Syahreni, E. (2011). Mengembangkan Perilaku Sehat Pada Anak 2-4 tahun. Direktorat Pembinaan Pendidikan Anak Usia Dini. http://www.paud.depdiknas.go.id/buletin/detail/mengembangkan-perilaku-sehatpada-anak-usia-2-4-tahun

Tanjung, R. (2020). Peran Orangtua dalam Pendidikan Anak Usia Dini di Masa Pandemi Covid-19. Murhum: Jurnal Pendidikan Anak Usia Dini, 1(2), 64-73. https://doi.org/10.37985/murhum.v1i2.18

Widiastita, N., \& Anhusadar, L. (2020). Bermain Playdough dalam Meningkatkan Kecerdasan Visual-Spasial Melalui Home Visit di Tengah Pandemi Covid-19. Murhum: Jurnal Pendidikan Anak Usia Dini, 1(2), 50-63. https:/ / doi.org/10.37985/murhum.v1i2.17

Wulandari, H., Purwanta, E., \& Kanak-kanak, T. (2021). Pencapaian Perkembangan Anak Usia Dini di TK selama Pembelajaran Daring saat Pandemi Covid-19. Jurnal Obsesi : Jurnal Pendidikan Anak Usia Dini, 5(1), 452-462. https:/ / doi.org/10.31004/obsesi.v5i1.626 